Reprod. Nutr. Dévelop., 1981, 21 (5A), 681-687.

\title{
Electrophysiological evidence for direct ecdysteroid action on the brain in Lithobius forficatus L. (Myriapoda : Chilopoda)
}

\author{
par M. DESCAMPS, B. LASSALLE
}

Laborotoire de Biologie animale, L.A. No 148 (Endocrinologie comparée des Invertébrés)

et Laboratoire de Morphogenèse animale.

Université des Sciences ef Techniques de Lille

59655 Villeneuve d'Ascq cedex, France.

Summary. Electrical activity of the brain of Lithobius forficatus has been recorded. The addition of ecdysteroids (moulting hormone) in the haemolymph increased the frequency and amplitude of electrical response. Such a stimulation might be specific to these products since cholesterol and juvenile hormone had no action.

The destruction or removal of various parts of the cephalic endocrine system demonstrated that the pars intercerebralis (p.i.) (postero-median area of the protocerebron) was responsible for increasing electrical activity after ecdysone supply.

\section{Introduction.}

A neuroendocrine feedback mechanism has been demonstrated both in vivo (Agui and Hiruma, 1977a ; Steel, 1978) and in vitro (Agui and Hiruma, 1977b) in the moulting cycle of insects. Furthermore, there is electrophysiological evidence of direct ecdysteroid action on the insect nervous system (Haskell and Moorhouse, 1963 ; Richter, 1979).

As in insects and crustacea, it has been shown in the centipede, Lithobius forficatus L., indirectly (Joly, 1964 ; Descamps, 1977) and directly (Joly et al., 1979), that the moulting hormone is an ecdysteroid. There is some evidence in favour of brain control of the moulting cycle : electrocoagulation of the median area of the protocerebron causes a decrease in the moulting percentage, and electrocoagulation of the frontal lobes of the protocerebron or removal of the cerebral glands leads to an increase in the moult ratio (Joly, 1966). Electrical stimulation of the same endocrine areas induces a respective increase and decrease in the moulting percentage (Joly and Descamps, 1977). The same endocrine centres are involved in the control of male (Descamps, 1974, 1975) and female (Herbaut, 1975, 1976) gamelogenetic cycles.

Previous histological studies (Descamps, 1974, 1975) demonstrated the specificity of the destroyed nervous areas, although the destruction of the pars intercerebralis (p.i.) was often incomplete. The neurosecretory cells (NSC) of this endocrine centre are located on at least one-half of the transverse posterior part of the protocerebron (Jamault-Navarro and Joly, 1977).

The aim of the present experiments was to (i) demonstrate the effects of ecdyste- 
roids and various compounds on brain electrical responses in $L$. forficatus, and (ii) determine the cerebral area involved in those responses.

\section{Material and methods.}

Experiments were carried out on adult male and female $L$. forficatus L. (maturus senior stage). The centipedes were anaesthetized with ethyl ether and the brain was stripped by removal of the cephalic cuticle.

Brain electrical activity was collected between a stainless steel extracellular electrode (non-insulated length : $0.25 \mathrm{~mm}$; apex diameter : $5.6 \mu \mathrm{m}$ ) on the p.i. (fig. 1) and

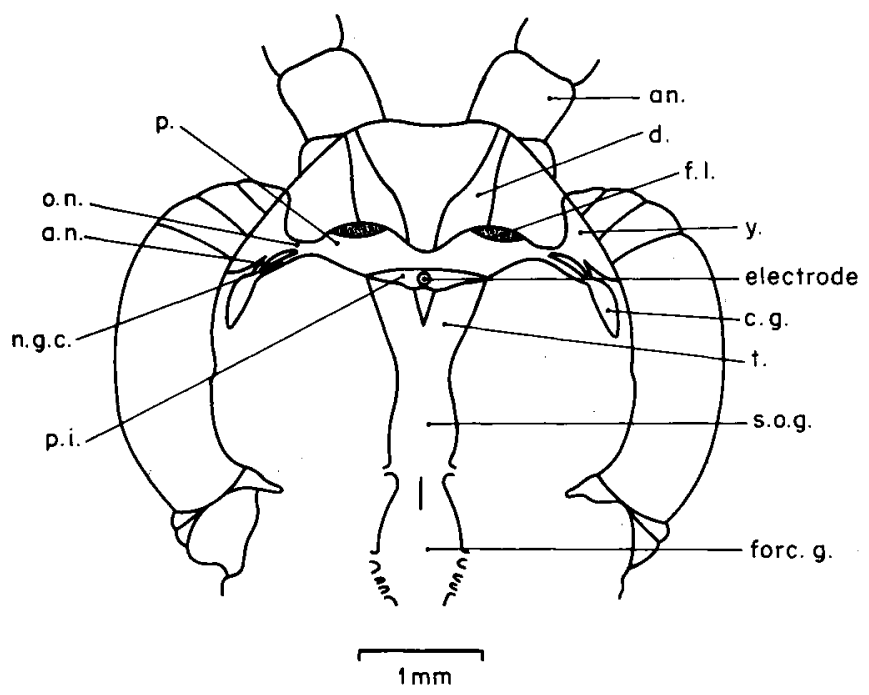

FIG. 1. - Anterior nervous system in L. forficatus.

an : antenna ; a.n. : accessory nerve of the cerebral gland ; c.g. : cerebral gland ; $\mathbf{d}$ : deutocerebron ; $\mathrm{fl}$ : frontal lobe ; forc. g. : forcipular ganglion; n.g.c. : nervus glandulae cerebralis ; o.n. : ocular nerve ; $p$ : protocerebron ; p.i. : pars intercerebralis ; s.o.g. : sub-œsophagal ganglion ; $t$ : tritocerebron ; y : eye.

an indifferent electrode (silver chloride ; $7 / 100-\mathrm{mm}$ diameter) introduced into the third truncal segment.

The electrical responses were recorded with a Tektronix 5031 oscilloscope after amplification with a differential preamplifier WP I with a bandwith fixed between $100 \mathrm{~Hz}$ and $30 \mathrm{KHz}$. In some cases, electrical activity was recorded on a tape recorder and the frequency analysed with a discriminator (Neurolog system).

$U_{p}$ to now, more accurate methods could not be used due to the small size of the brain and the difficulty in localizing the different types of neurons and neurosecretory cells.

We first recorded the basal electrical activity and then the activity resulting from various solutions added into the haemolymph with a Hamilton syringe. Several solufions were tested : Ringer (Ephrussi and Beadle, 1936) ; Ringer with 10 p. 100 ethanol ; 
$1 \mu \mathrm{g} / \mu \mathrm{l}$ solutions or $\alpha$-and $\beta$-ecdysone (Simes) in Ringer-10 p. 100 ethanol. Cholesterol is soluble in ethanol but flocculates in Ringer ; therefore we used an opalescent colloidal Ringer-10 p. 100 ethanol solution $(1 \mu \mathrm{g} / \mu \mathrm{l})$. 7-dehydrocholesterol $(1 \mu \mathrm{g} / \mu \mathrm{l}$ in Ringer-10 p. 100 ethanol), used as a control by Richter (1979), was also tested. Finally, we also employed juvenile hormone (JH1) in sunflower oil $(1.6 \mu \mathrm{g} / 10 \mu \mathrm{l})$.

Three types of experiments were carried out : (i) bilateral electrocoagulation of the neurosecretory cells (NSC) of the frontal lobes (antero-lateral area of the protocerebron); most of the axons of these cells end in the cerebral glands ; (ii) removal of the cerebral glands; (iii) electrocoagulation of the NSC of the pars intercerebralis (postmedian area of the protocerebron).

\section{Results.}

The various experiments, each including 5 to 10 centipedes, showed that only basat electrical activity (i.e., fig. 2a) was recorded in the brain of anaesthetized animals. Locomotor activity was not involved in basal activity; indeed, when the centipedes woke up, the spike amplitude increased from about $80 \mu \mathrm{V}$ to $400-500 \mu \mathrm{V}$.

The basal electrical activities were not the same in the different animals so a control was recorded for each one. No change in brain electrical activity was observed after the addition of Ringer or Ringer-10 p. 100 ethanol (fig. 5). But the addition of 0.5 to $1 \mathrm{ug}$ of ecdysteroids (amounts inducing experimental moulting ; Joly, 1964 ; Descamps, 1977), after a latency period of 20 to $60 \mathrm{sec}$., augmented electrical activity in all cases (figs. $2 b, 3 b, 4 b$ ) : increase in spike amplitude and spike frequency [from $1-3 \mathrm{~Hz}$ in controls to $10-18 \mathrm{~Hz}$ after ecdysone supply (fig. 9)]. High-speed recordings show that

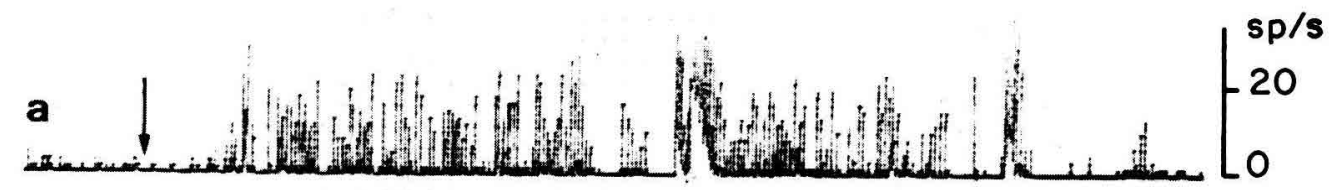

$60 \mathrm{~s}$

FIG. 9. - Graphic recording of the discharge frequency (spikes/second) of the pars intercerebralis of Lithobius ofter $\beta$-ecdysone supply $(1 \mu \mathrm{g})$.

Horizontal bar : $60 \mathrm{sec}$; a : basal activity ; arrow : $\beta$-ecdysone supply.

the spikes are essentially triphasic (fig. 6). These increases continued for 1 to $3 \mathrm{~min}$. and could be induced by a very small amount of ecdysteroid : $0.05 \mu$ of solution, i.e. $50 \mathrm{ng}$ of the active product. In that case, electrical response was shorter (about $30 \mathrm{sec}$.) than after 0.5 to $1 \mu \mathrm{g}$ of ecdysteroid was supplied. The increased electrical activity could be cancelled if the brain was washed with Ringer solution, in which case only basal elecfrical activity appeared.

There was no change in brain electrical activity after the addition of cholesterol ( $1 \mu \mathrm{g}$ per animal) (fig. 7) or $\mathrm{JH} 1$ solutions $(0.16 \mu \mathrm{g}$ per animal).

To study the destruction of the frontal lobes of the protocerebron, 26 centipedes 


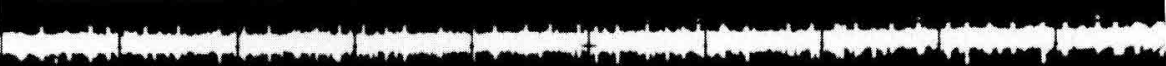

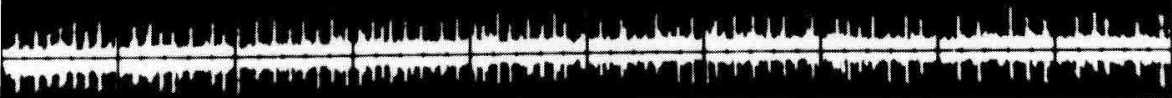

Pmom

$3 a$

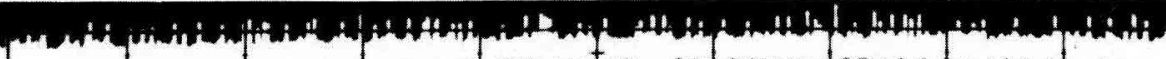

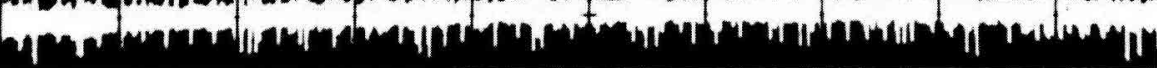

$3 b$

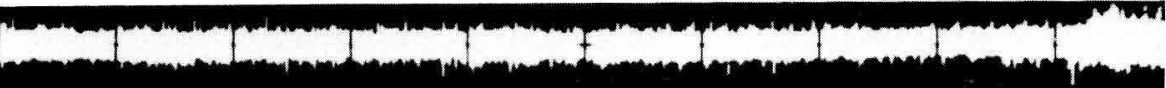

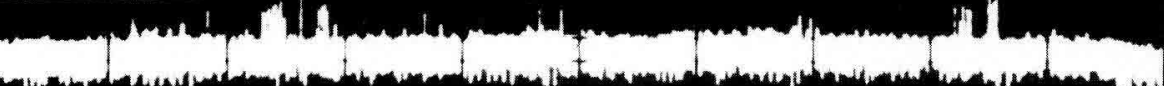
$4 b$

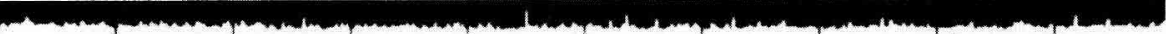
com

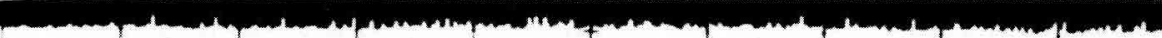

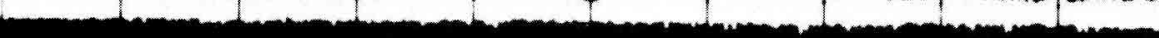

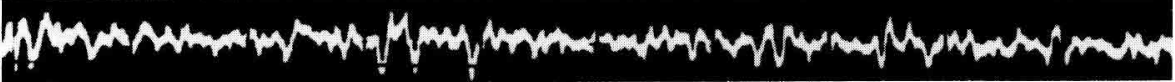

$6 a$

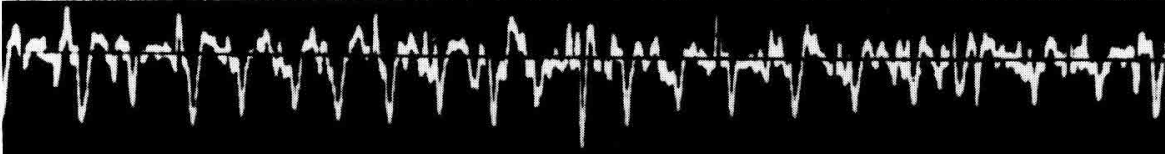

$6 b$

(1)

$7 \mathbf{a}$

$7 \mathrm{~b}$

(T)

$8 \mathbf{a}$

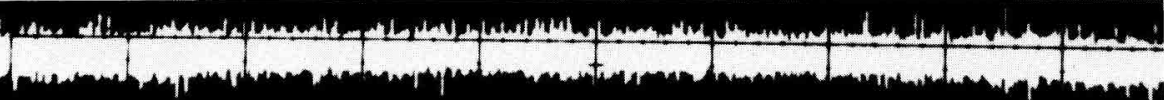


were tested $8,15,30$ or 60 days after the experiments began. In all cases, $\beta$-ecdysone supply led to an increase in cerebral electrical activity (fig. 8).

Fourteen centipedes were tested 8 or 30 days after their cerebral glands had been surgically removed. Ecdysone supply led to an increase in electrical activity, although spike amplitude was generally less than in the controls.

The ecdysone supply did not cause any electrical reaction in 70 p. 100 of the 20 centipedes tested 6, 15, 30 or 60 days after electrocoagulation of the pars intercerebralis. Many of the remaining animals showed a short-lived reaction.

\section{Discussion.}

Ecdysteroids induced an increase of brain electrical activity in Lithobius forficatus and acted either on the frequency and/or on the amplitude, as in insects (fig. 1a, $b$; in the paper of Haskell and Moorhouse, 1963).

The increase in spike amplitude and frequency suggests that ecdysteroids stimulated nervous activity both in the area under the electrode and in more distant structures. The overall increase of electrical activity was thus related, on the one hand, to the fact that previously silent structures were activated and, on the other, to a spatial and temporal recruitment of nervous unit activity. Triphasic potentials appearing on the high-speed recordings reflect the electrical activity of the nervous p.i. components (cells and fibres; Jamault-Navarro and Joly, 1977) which was collected by the external electrode in that endocrine area.

The rapidity of the reaction to ecdysone supply may be related to a membrane effect, as found in the case of other steroid hormones : the action of progesterone and some other steroids (Baulieu et al., 1978 ; Godeau ef al., 1978) on the meiotic maturation of the Xenopus laevis oocyte and the effect of oestradiol compounds on the electrical activity of mammalian hypothalamic neurons (Kelly ef al., 1977 ; Carette et al., 1979). Ecdysteroids also have a neurodepressing effect on the electrical activity of insect motor neurons (Haskell and Moorhouse, 1963 ; Richter, 1979) where a quick response is also found. So, it would seem that ecdysteroid action on the electrical activity of arthropodian neurons is the third example of a steroid membrane effect.

In $L$. forficatus, neither the neurons of the frontal lobes nor those of the cerebral glands are responsible for the increased electrical activity. The site of ecdysteroid action seems to be in the pars intercerebralis since, after that area was destroyed, the ecdysone reaction disappeared. If some of the operated centipedes showed a response, it was probably because the cells were not completely destroyed.

FIGS. 2 to 8. - Oscilloscope recordings of electrical activity of the p.i. in L. forficatus. In all figures, $a$ : control ; $b$ : after addition of the tested product.

2 and $3: \beta$-ecdysone $(1 \mu \mathrm{g}) ; 4: \alpha$-ecdysone $(1 \mu \mathrm{g}) ; 5$ : Ringer-10 p. 100 ethanol $(10 \mu \mathrm{l}) ; 6$ : highspeed recording after $\alpha$-ecdysone supply $(0,8 \mu \mathrm{g}) ; 7$ : Cholesterol $(1 \mu \mathrm{g}) ; 8$ : Effect of $\beta$-ecdysone supply $(1 \mu \mathrm{g})$ after destruction of the protocerebral frontal lobes (15 days after surgery).

Scales (in lower right-hand corner) : horizontal bar, $1 \mathrm{sec}$ (except fig. $6: 20 \mathrm{msec}$ ) ; vertical bar, $100 \mu V$ (except $2: 200 \mu \mathrm{V}$ ). 
The lower amplitude of response observed in centipedes deprived of cerebral glands may be related to the decrease in neurosecretory activity of the p.i. NSC observed after surgery (Jamault-Navarro, 1979).

The increase in p.i. electrical activity seems to be specific to the moulting hormone since neither cholesterol, a precursor of that hormone, nor 7-dehydrocholesterol had any effect. It should be pointed out that $\beta$-ecdysone (and hormone analogs) is highly specific; Cherbas et al. (1980) demonstrated that 27 intermediate compounds in ecdysone synthesis (Lee ef al., 1976) had no action on a Drosophila cell culture.

$\mathrm{JH} 1 \mathrm{had}$ no effect, at least on brain activity. There is only presumptive evidence for the presence of juvenile hormone in Myriapoda (unpublished data). Moreover, a mimic of $\mathrm{JH}$, farnesyl-methyl-ether, acts on L. forficatus spermatogenesis (Descamps, 1980).

Reçu en avril 1980.

Accepté en ovril 1981.

Acknowledgements. - We are very grateful to Drs. P. Poulain and B. Carette (Lab. INSERM U. 156 ; Director: Professor J. Barry) for the use of the Neurolog system.

Résumé. Chez Lithobius forficatus, l'addition d'ecdysone (hormone de mue) à l'hémolymphe entraîne une stimulation de l'activité électrique cérébrale. L'augmentation de la fréquence et de l'amplitude des signaux enregistrés semble spécifique des ecdystéroïdes, le cholestérol ou l'hormone juvénile n'ayant aucune action.

L'emploi des techniques sélectives de destruction ou d'ablation des différentes régions endocrines impliquées dans le contrôle de la mue et de la gamétogenèse a permis de préciser le lieu d'action de l'ecdysone. Seules les cellules de la pars intercerebralis (région postéro-médiane du protocérébron) semblent intervenir.

\section{References}

AGUI N., HIRUMA K., 1977a. Ecdysone as a feedback regulator for the neurosecretory brain-cells in Mamestra brassicae. J. Insect Physiol., 23, 1393-1396.

AGUI N., HIRUMA K., 1977b. In vitro activation of neurosecretory brain cells in Mamestra brassicae by 3-ecdysone. Gen. comp. Endocr., 33, 467-472.

BAULIEU E. E., GODEAU F., SCHORDERET M., SCHORDERET-SLATKINE S., 1978. Steroidinduced meiotic division in Xenopus laevis oocytes : surface and calcium. Nafure, 275, 593-598.

CARETTE B., BARRY J., LINKIE D., FERIN M., MESTER J., BAULIEU E. E., 1979. Effets de l'« œstradiol-7 $\alpha$-butyrique " au niveau des cellules hypothalamiques. C. R. Acad. Sci. Paris, Sér. D, 288, 631-634.

CHERBAS L., YONGE C. D., CHERBAS P., WILLIAMS C. M., 1980. The morphological response of $\mathrm{KC}-\mathrm{H}$ cells to ecdysteroids : hormonal specificity. Wilhelm Roux's Arch., 189, 1-15.

DESCAMPS M., 1974. Etude du contrôle endocrinien du cycle spermatogénétique chez Lithobius forficatus L. (Myriapode Chilopode). Rôle de la pars intercerebralis. Gen. comp. Endocr., 24, 191-202.

DESCAMPS M., 1975. Ełude du contrôle endocrinien du cycle spermatogénétique chez Lithobius forficafus L. (Myriapode Chilopode). Rôle du complexe «cellules neurosécrétrices des lobes frontaux du protocérébron-glandes cérébrales ». Gen. comp. Endocr., 25, 346-357.

DESCAMPS M., 1977. Influence de la croissance somatique sur le cycle spermatogénétique de Lithobius forficatus L. (Myriapode Chilopode). Gen. comp. Endocr., 33, 412-422.

DESCAMPS M., 1980. Influence d'un mimétique de l'hormone juvénile sur le cycle spermatogénétique de Lithobius forficatus L. (Myriapode Chilopode). Journ. Soc. zool. Fr., Poitiers, Bull. Soc. zool. Fr., $105,57-63$. 
EPHRUSSI B., BEADLE G. W., 1936. A technique of transplantation for Drosophila. Amer. Nafur., 70, 218-225.

GODEAU F., SCHORDERET-SLATKINE S., HUBERT P., BAULIEU E. E., 1978. Induction of maturation in Xenopus laevis oocytes by a steroid linked to a polymer. Proc. nat. Acad. Sci. USA, 75, 2353-2357.

HASKELL P. T., MOORHOUSE J. E., 1963. A blood-borne factor influencing the activity of the central nervous system of the desert locust. Nature, 197, 56-58.

HERBAUT C., 1975. Etude expérimentale de l'ovogenèse chez Lithobius forficatus L. (Myriapode Chilopode). Rôle de la pars intercerebralis. Gen. comp. Endocr., 27, 34-42.

HERBAUT C., 1976. Etude expérimentale de la régulation endocrinienne de l'ovogenèse chez Lithobius forficatus L. (Myriapode Chilopode). Rôle du complexe « cellules neurosécrétrices protocérébrales-glandes cérébrales ». Gen. comp. Endocr., 28, 264-276.

JAMAULT-NAVARRO C., 1979. Contribution à l'éfude du système endocrinien céphalique chez Lithobius forficatus (Myriopode Chilopode). Th. 3e cycle, 84 pp. + 21 pl. h.t. - Univ. Picardie.

JAMAULT-NAVARRO C., JOLY R., 1977. Localisation et cytologie des cellules neurosécrétrices protocérébrales chez Lithobius forficatus L. (Myriapode Chilopode). Gen. comp. Endocr., 31, 106-120.

JOLY R., 1964. Action de l'ecdysone sur le cycle de mue de Lithobius forficatus L. (Myriapode Chilopode). C. R. Soc. Biol., 158, 548-550.

JOLY R., 1966. Contribution à l'étude du cycle de mue et son déterminisme chez les Myriapodes Chilopodes. Bull. biol. France Belg. C, 3, 379-480.

JOLY R., DESCAMPS M., 1977. Influence de l'électrostimulation cérébrale sur l'histologie ultrastructurale et le rôle physiologique des glandes cérébrales chez Lithobius forficatus L. (Myriapode Chilopode). Arch. Biol., 88, 333-347.

JOLY R., PORCHERON P., DRAY F., 1979. Etude des variations du taux d'ecdystéroïdes au cours du cycle de mue dans l'hémolymphe de Lithobius forficatus L. (Myriapode Chilopode) par dosage radioimmunologique. C. R. Acad. Sci. Paris, sér. D, 288, 243-246.

KELLY M. J., MOSS R. L., DUDLEY C. A., FAWCETT C. P., 1977. The specificity of the response of preoptic-septal area neurons to oestrogen : $17 \alpha$-œstradiol versus $17 \beta$-oestradiol and the response of extrahypothalamic neurons. Exp. Brain Res., 30, 43-52.

LEE E., LIU Y. T., SOLOMON P. H., NAKANISHI K., 1976. Stereospecific conversion of diosgenin to $\alpha$-ecdysone. J. am. chem. Soc., 83, 1634-1635.

RICHTER K., 1979. Zur Wirkung von Ecdysteron auf eine periphere motorische Nervenaktivität bei der Schabe Periplaneta americana L. Zool. Jb. Physiol., 83, 350-360.

STEEL C. G. H., 1978. Nervous and hormonal regulation of neurosecretory cells in the insect brain, 327-330. In GAILLARD P. J., BOER H. H., Comparative endocrinology, Elsevier-North-Holland Biomed. Press, Amsterdam. 